\author{
Journal of International Business Research and \\ Marketing \\ Volume 6, Issue 2, 2021 \\ journal homepage: www.researchleap.com
}

\title{
Balance Sheet Model for Small Economic Entities
}

\author{
${ }^{1}$ Halina Chlodnicka, ${ }^{2}$ Grzegorz Zimon \\ ${ }^{1,2}$ Rzeszow Univerisity of Technology, Poland
}

\begin{tabular}{|l|l|}
\hline & ABSTRACT \\
\hline 2021 Research Leap/Inovatus Services Ltd. & $\begin{array}{l}\text { Financial reporting still raises doubts and concerns among large and small entrepreneurs. When } \\
\text { analyzing financial statements, the recipient often asks whether the current comprehensive forms } \\
\text { of financial statements are not too vague and confusing. Data disclosed in the financial statements } \\
\text { are often not easily read by ordinary users or even analysts. Maybe now it is worth looking for } \\
\text { oOI: } 10.18775 / \text { jibrm.1849-8558.2015.62.3001 } \\
\text { URL: } \text { http://dx.doi.org/10.18775/jibrm.1849- } \\
\text { the financial reports in a quick and immediate way. The increase in competition and financial } \\
\text { crises caused the largest number of bankruptcies in the group of small and medium enterprises. } \\
\text { Keywords: }\end{array} \quad \begin{array}{l}\text { And it is to these small economic entities that it is worth facilitating the process of analyzing } \\
\text { financial data. For this group of enterprises, it is worth highlighting in the financial statements } \\
\text { those data that may inform about risks in conducting and continuing further operations. The } \\
\text { article presents a balance sheet model for small business entities. Its layout and formula is } \\
\text { designed to lighten the picture of the company's financial situation and provide the most important } \\
\text { information on the company's financial safety. }\end{array}$ \\
& \\
\hline
\end{tabular}

\section{Introduction}

Financial reporting is one of the main accounting functions, as emphasized by (Paczuła 2005), stating that "both theoreticians and practitioners draw attention to one of the main accounting functions in the unit, what is the reporting function". Also (Walińska 2012), stated that "the reporting function plays the most important role in the information system of the economic entity". At the same time, it is recommended that the reports prepared and presented should be useful in assessing the management of the unit and management's responsibility for the resources entrusted, and should enable economic decisions to be made. How to prepare a report in such a way that the information is legible, transparent for investors, etc. and serves management purposes for management? Over the years, the information content and the construction of financial reports have changed significantly. Their shape and compactness were not detailed in the regulations and therefore their content resulted from the information needs of recipients (Jędrzejewski et al. 2012). Does the intelligibility of information mean that the data presented in the financial statements should be easily used in the process of making business decisions by their users? According to the author, the report should contain only such information that is necessary for external users and they will make the decisions they need, while the information for internal decisions is a completely different kind of report.

\section{Literature Review}

Currently, the debate on the adequacy of disclosed information by companies is growing. Among the possible available funds, management reports are important to enable investors and other users to formulate a reasoned opinion on the company operations and situation (García 2012). The data presented in the financial statements are hard to read for ordinary users, and for many analysts a bit unclear (Gotti 2016). These authors believe that they are illegible and provide low-quality information, even the adoption by German or Spanish companies IFRS does not improve their readability (Chen et.al 2010; Van Tendello, Vanstraelen 2005; Ahmed et al. 2013; Palea 2017; Caleo, 2007). Readability of reports and short information flow could protect many entities from the risk of bankruptcy (Chłodnicka and Zimon 2017, Sadowski 2018). This is particularly true for small business entities that do not benefit from simplifications. The structure of entities which in the years 2010-2017 declared bankruptcy including their legal form was presented as follows: sp. Z o.o. (58.4\%), natural person (22.6\%), joint-stock company (7.8\%), general partnership (4.2\%), limited partnership (2.6\%), cooperative $(2.1 \%)$, a civil partnership $(1.4 \%)$, others $(0.9 \%)$ (Dankiewicz 2018). The reasons are different. In general, payment delays and poorly selected short-term receivables management strategy badly affects the financial security of enterprises, (Zimon D 2019a; Zimon D 2019b; Zimon D 2018). For many years, entities that are limited liability companies 
constitute the largest share among bankrupt entities. Therefore, it is important to look at these smaller business entities to have their information available one that would save them from bankruptcy.

\section{The Essence of Economic Entities}

The definitions, essence and classification of these smaller entities, i.e. micro, small and medium ones, are presented in table 1 .

Table 1: Classification of business entities

\begin{tabular}{|c|c|c|}
\hline Legal act & Criterion & $\begin{array}{l}\text { Type } \\
\text { of } \\
\text { entity }\end{array}$ \\
\hline $\begin{array}{l}\text { Accounting } \\
\text { Act } \\
\text { JOL } 2019 \\
\text { item } 351 . \\
\text { Article } 3 \text {, } \\
\text { paragraph } \\
\text { 1c, point } 1\end{array}$ & $\begin{array}{l}\text { did not exceed at least two of the } \\
\text { following three values: } \\
\text { - } 10 \text { people - in the case of average } \\
\text { annual employment in full-time } \\
\text { equivalents, } \\
\text { - PLN } 3,000,000 \text { - in the case of net } \\
\text { revenues from the sale of goods and } \\
\text { products for the financial year; } \\
\text { - PLN } 1,500,000 \text { - in the case of total } \\
\text { balance sheet assets at the end of the } \\
\text { financial year } \\
\text { they have not exceeded at least two of } \\
\text { the following three volumes: } \\
\text { - } 50 \text { people - in the case of average } \\
\text { annual employment in full-time } \\
\text { equivalents, } \\
\text { - PLN } 51 \text { million - in the case of net } \\
\text { revenues from sales of goods and } \\
\text { products for the financial year, } \\
\text { - PLN } 25500000 \text { - in the case of } \\
\text { total balance sheet assets at the end } \\
\text { of the financial year, }\end{array}$ & micro \\
\hline $\begin{array}{l}\text { Art.3 } \\
\text { paragraph } \\
\text { 1a point } 1\end{array}$ & $\begin{array}{l}\text { they have not exceeded at least two of } \\
\text { the following three volumes: } \\
\text { - } 50 \text { people - in the case of average } \\
\text { annual employment in full-time } \\
\text { equivalents, } \\
\text { - PLN } 51 \text { million - in the case of net } \\
\text { revenues from sales of goods and } \\
\text { products for the financial year, } \\
\text { - PLN } 25500000 \text { - in the case of } \\
\text { total balance sheet assets at the end } \\
\text { of the financial year, }\end{array}$ & small \\
\hline $\begin{array}{l}\text { Entrepreneu } \\
\text { rs Law } \\
2018 \text { item } \\
646 \\
\text { art.7. } \\
\text { paragraph } \\
1 \text {, points } 1 \text {, } \\
2,3\end{array}$ & $\begin{array}{l}\text { an entrepreneur who, in at least one year } \\
\text { of the last two financial years, met all of } \\
\text { the following conditions: } \\
\text { - employed on average less than } 10 \\
\text { employees per year and } \\
\text { - has achieved annual net turnover } \\
\text { from the sale of goods, products and } \\
\text { services and from financial operations } \\
\text { not exceeding the PLN equivalent of } \\
\text { EUR } 2 \text { million, or } \\
\text { - the total assets of its balance sheet } \\
\text { prepared at the end of one of these } \\
\text { years did not exceed the PLN } \\
\text { equivalent of EUR } 2 \text { million }\end{array}$ & micro \\
\hline
\end{tabular}

an entrepreneur who, in at least one year $\quad$ small of the last two financial years, met all of the following conditions:

- employed annually less than 50 employees and

- has achieved annual net turnover from the sale of goods, products and services and from financial operations not exceeding the PLN equivalent of EUR 10 million, or

- the total assets of its balance sheet prepared at the end of one of these years did not exceed the PLN equivalent of EUR 10 million an entrepreneur who, in at least one year medium of the last two financial years, met all of the following conditions:

- employed annually less than 250 employees and

- has achieved annual net turnover from the sale of goods, goods and services and from financial operations not exceeding the PLN equivalent of EUR 50 million, or

- the total assets of its balance sheet prepared at the end of one of these years did not exceed the PLN equivalent of EUR 43 million an entrepreneur who met all the following conditions:

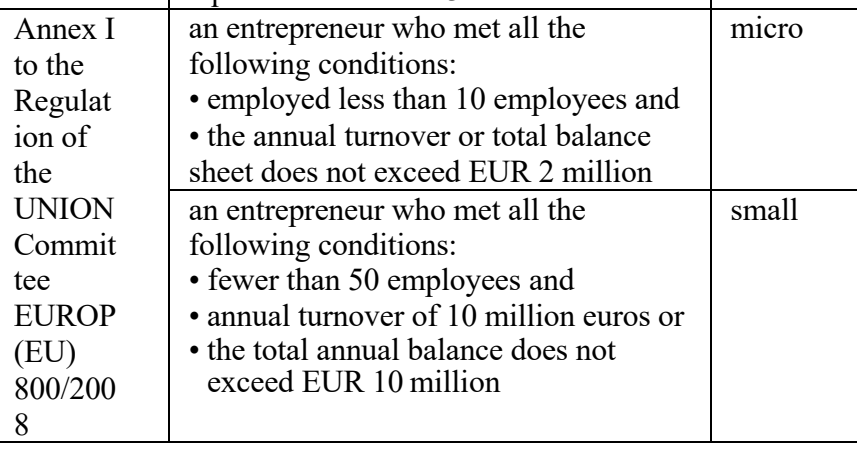

Source: Author's own study based on the above-mentioned laws

As shown in the table, the criteria for division according to the Entrepreneurs' Law duplicates the criteria developed in the European Commission Regulation. Different criteria for the division of economic entities are presented in the Accounting Act, and according to these criteria, financial reporting applies. However, when analyzing the above criteria for medium- sized entities defined in other acts, such reporting will apply as for small entities in accordance with the Accounting Act. Many simplification changes have been introduced, especially for micro and small entities, but here too the application criteria have been introduced. As it follows from art. 7 par. $2 b$ of the current year, a micro, small and an entity may resign from the prudence principle when valuating individual assets and liabilities in the area of impairment write-downs of assets and provisions for known risk, losses and the effects of other events. In turn, on the basis of art. 32 par. 7 and 33 par. 1 and art. 39 par. 6 these units may also (the Accounting Act):

- make depreciation or redemption write-offs on tangible and intangible fixed assets according to the rules set out in tax regulations, 
- do not create passive accruals of expenses related to future employee benefits, including retirement benefits (Chłodnicka 2018).

The above simplifications, however, do not apply to limited liability companies, limited joint- stock partnerships and general or limited partnerships whose all partners with unlimited liability are capital companies, limited joint-stock partnerships or companies from other countries with a legal form similar to those of the companies. The conclusion is that instead of increasing the limits for operating micro and small entities and allow a simplification, it may be worth considering changing the formula of the full report and making changes so that individuals who cannot benefit from simplifications also had easier to prepare, read and analyze financial statements. The submitted financial statements (Lew 2016; Sadowska 2014) have a negative impact on the information environment.

\section{Balance Sheet Model for Small Entities}

Doubts about the clarity of informational financial statements caused an attempt to build a new balance sheet formula (table 2).

Table 2: Information system in the unit balance sheet

\begin{tabular}{|c|c|}
\hline ASSETS & LIABILITIES \\
\hline \multicolumn{2}{|c|}{ A BASIC OPERATIONAL ACTIVITY - part $A$} \\
\hline $\begin{array}{ll}\text { A. } & \text { Fixed assets: } \\
\text { - } & \text { Intangible assets } \\
- & \text { Tangible fixed assets } \\
\text { - } & \text { Long-term receivables: } \\
- & \text { Long-term investments } \\
\text { - } & \text { Estates } \\
\text { - } & \text { Intangible assets } \\
\text { - } & \text { loans granted } \\
- & \text { Long-term prepayments }\end{array}$ & $\begin{array}{l}\text { A. Equity: } \\
\text { - Share capital } \\
\text { - others, including: } \\
\text { Revaluation reserve } \\
\text { - Net profit (loss) } \\
\text {-profits retained }\end{array}$ \\
\hline \begin{tabular}{|l} 
B. Current asstes: \\
- Inventory \\
- Receivables; \\
- trade \\
- other \\
- loans granted \\
- Money at hand and in bank \\
accounts from operating \\
activities \\
cash in hand and at bank \\
- Settlement of construction \\
contracts \\
- other assets
\end{tabular} & $\begin{array}{l}\text { B. Liabilities } \\
\text { - Long-term liabilities: } \\
\text { - credits and loans } \\
\text { - othes } \\
\text { - Short-term liabilities: } \\
\text { - credits and loans } \\
\text { - trade liabilities } \\
\text { - Settlement of construction } \\
\text { contracts } \\
\text { - Special funds }\end{array}$ \\
\hline \multicolumn{2}{|c|}{ RETURN TO SECURITIES - part B } \\
\hline $\begin{array}{l}\text { Financial instruments: } \\
\text { - Long-term financial assets } \\
\text { - Short-term financial assets } \\
\text { - Money from trading in } \\
\text { securities }\end{array}$ & $\begin{array}{l}\text { Equity: } \\
\text { - Financial instruments } \\
\text { issued } \\
\text { - others, including: } \\
\text { - from the revaluation } \\
\text { - Net result on } \\
\text { trading in } \\
\text { financial } \\
\text { instruments }\end{array}$ \\
\hline
\end{tabular}

- retained earningsfinancial liabilities

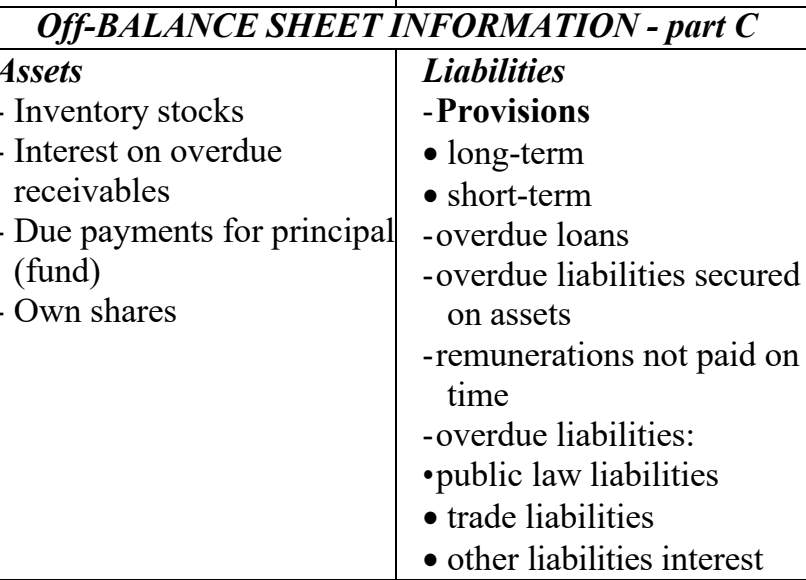

Source: author's own study

As it can be seen from the table, the proposed formula consists of three parts:

- A - regarding operating activities.

- $\mathrm{B}$ - regarding trading in securities.

- $\quad \mathrm{C}$ - related to information that may be a threat to going concern as part of off-balance sheet information.

Part A is the part where only information on operational activities would be presented, which would help entrepreneurs to assess quickly the situation of this activity. In this part, no short- term settlements, both active and passive, have been specified.

It seems that they do not have a significant impact on the assessment of the financial situation, and most of the recipients simply do not see such information, so they can be recognized as other assets or other liabilities. In addition, the provisions of the Accounting Act in the article 39 make passive settlements virtually a non-active item. Important information related to interim short-term settlements is the settlement of long-term contracts, but it can be demonstrated as a separate item. When asked, entrepreneurs who run this type of activity did not know where the settlement of construction contracts is currently being reported. The elimination of a separate item of accrued expenses means that it would be illegible to demonstrate negative goodwill. Negative goodwill - it would be worth considering whether to use international solutions and not to include this value in the balance sheet only as a gain on a bargain acquisition and recognized as a result of acquisition, but only for related entities. Separation of cash separately for operating activities and operations from trading in securities seems to be very clear information. In addition, financial liquidity and net working 
capital will play a very important role in analyzing the financial security of enterprises. However, for these measures, one needs to pay attention to part $\mathrm{C}$ of the balance sheet, i.e. off-balance sheet information. The basic capital from part A is capital injected in the form of cash, goods or shares. The elimination of provisions in Part A will reduce the manipulation of the financial result. Provisions would be included in part $\mathrm{C}$, and at the moment of actual occurrence would become a real obligation. The financial result in part A is a purely operational result. The level of basic capital would be important information, especially for the environment on the company's competitive position. Its high level would raise the company's reputation, which would allow the company to gain an advantage over the competition, the growth and aggressive policy of which strongly impairs the management of the enterprise. Part B would concern investment in securities trading. The specification of this information would belong to the entity, depending on the nature, scope of such transactions. Many entrepreneurs do not have this type of operation, so this part would be zeroed for them, which would be a clearer part of A. Including such instruments together with operating activities may in many cases improve the overall picture of the entity and improve indicators. Trading in securities creates a greater risk. The results created from their turnover may be short-term, due to the various influencing external factors, which affects their value. Such instruments have a varying degree of risk, so this information is not needed at the moment in the main part of the report, that is part A. From interviews and consultations with entrepreneurs it follows that most do not know what is in the balance in their current form, because it's too much. The basic capital from part B is the capital created for the transfer of value through securities. An application of part $\mathrm{C}$ to the main part of the report would facilitate a quick assessment. A lot of information can be found in the additional information. The intention of the new formula is to present information in the balance sheet. Additional information is constantly growing, and this causes that often entrepreneurs do not want to explore even the basic part of the report, but only to read additional information. The new formula allows to clearly present possible threat signals as well as the current situation of the business entity. The disclosure in Part $\mathrm{C}$ above all may be helpful to the entity, it will mobilize to descend from such positions, it will be possible to react to the deterioration of the assessment results, and it will be possible to find a shorter, faster way to look for the investor. Even an investor who has such information can offer help himself. Inventories, whether receivables shown in part A for which revaluation write-offs have been made do not inform exactly what value in detail for inventories and receivables, the general value is read from the profit and loss account. One could also opt out of revaluation write-offs, and obsolete stocks, overdue receivables or interest on receivables set out in Part $\mathrm{C}$ provide detailed information. Then the result on the operating activity would be clean, without artificially created costs. Write-downs would be made at the time of inventory management, expiry of receivables, etc.
Presentation of off-balance sheet items on the side of assets and liabilities can change the quality of the indicators of the assessment of the financial situation. The refinement of individual parts would depend on the given entity. We hope that the formula proposed will be the beginning of a discussion on this subject, as well as changes in financial reporting in Poland and in the world. The US Steel Report of 1920 is a small, 40page document, while its counterpart from 2012, in the best, had 174 pages, which certainly obscured the information picture. In the report for 2012 there are a lot of different analyzes, charts, financial data exhibits that adorn the report (Lev, Feng 2016).

\section{Conclusion}

The accuracy of economic decisions depends on the quality of financial information, mainly derived from financial statements prepared by business or other entities. It happens that among the participants of economic turnover the information presented remains unintelligible. In this respect, it is expected that universal, transparent, readable, short financial reports will be a reliable source of information. Therefore, in order primarily to protect the diverse interests of recipients of this information, it is extremely important to adhere to the quality features that should be met by created information. The proposition of the authors of the article refers primarily to small units that cannot use simplifications in financial statements. Currently, many things are transferred to additional information and explanations. Its volume is growing every year and who actually reads it. The balance sheet model presented in a transparent way features the most important information that the company managers should clearly and legibly receive.

\section{References}

- Ahmed, S., Neel, M., Wang, D., (2013). Adoption of ifrs improve accounting quality? Preliminary evidence. Contemp. Account. Res. $\underline{\text { Crossref }}$

- Callao, S., Jarne, J. I., \& Lainez, J. A. (2007). Adoption of IFRS in Spain: Effect on the comparability and relevance of financial reporting. Journal of InternationalAccounting, Auditing and Taxation, 16(2). Crossref

- Chen, H., Tang, Q., Jiang, Y., Lin, Z., (2010). The role of international financial reporting standards in accounting quality: evidence from the European Union. J. Int. Financ. Manage. Account. 21. Crossref

- Chłodnicka H. (2018), System informacyjny a przydatność sprawozdań finansowych, Prace Naukowe Uniwersytetu Ekonomicznego we Wrocławiu z. .

- Chłodnicka, H., Zimon G., (2017). Financial Situation Assessment Dilemmas of Selected Capital Groups [in:] Proceedings of the 2nd International Scientific Conference: Central European Conference in Finance and Economics (CEFE 2017): September 20-21, 2017: Herl'any, Slovak Republic, (ed.) Beáta Gavurová, Michal Šoltés, 2017, Koszyce: TECHNICAL UNIVERSITY OF KOSICE

- Dankiewicz R. (2018). Zjawisko upadłości przedsiębiorstw w Polsce. Kierunki i przyczyny zmian, Economic Policy in the Europen Union Member Courtries, Silesion University in Opava. 
- García, P. (2012). La supervisión de la información financiera y corporativa de las entidades cotizadas y otros aspectos relacionados. Aeca, 100, diciembre.

- Gotti, G., (2016). Discussion of Segment Disclosure Quantity and Quality under IFRS 8: Determinants and the Effect of Financial Analysts Earnings Forecast Errors, The International Journal of Accounting 51. Crossref

- Jędrzejewski, S, Urbaszek M., Kowalczyk M., (2012). Ewolucja systemu rachunkowości polskiej w okresie dwudziestolecia międzywojennego, SIZ, Łódź.

- Lev, B., Feng G.., (2016). The End of Accounting and the Path Forward for Investors and Managers, New Jersey, John Willey end Sons. Crossref

- Lew, G., (2016). Sporządzanie sprawozdań finansowych, [w]: Rachunkowość. Zasady i metody. Polskie Wydawnictwo Ekonomiczne, Warszawa.

- Międzynarodowe Standardy Sprawozdawczości Finansowej, 2013, SKwP, IASB, Warszawa, MSSF 3.

- Paczuła, C.,(2005). Rachunkowość, finanse i bilanse w praktyce przedsiębiorstw, LexisNexis, Warszawa.

- Palea, V., (2014). TaxationAre IFRS value-relevant for separate financial statements? Evidence from the Italian stock market, Journal of International Accounting, Auditing and Taxation 23 (2014). $\underline{\text { Crossref }}$

- Sadowska, B. (2014). Znaczenie i warunki stosowania zintegrowanych systemów informatycznych w sferze budżetowej. Zeszyty Teoretyczne Rachunkowości, (76).

- Sadowska, B. (2018). Rachunkowość zarządcza jako element zintegrowanego systemu informacyjnego jednostki gospodarczej. Zeszyty Teoretyczne Rachunkowości, (98). Crossref

- Ustawa z dnia 29 września 1994 r. o rachunkowości. (Dz. U. 2019).

- Van Tendeloo, B., Vanstraelen, A., (2005). Earnings management under German GAAP versus IFRS. Euro. Account. Rev. . Crossref

- Walińska E., (2012). Rachunkowość. Rachunkowość i sprawozdawczość finansowa, Wolters Kluwer Warszwa, p.

- Zimon D., Zimon G., (2019b). The Impact of Implementation of Standardized Quality Management Systems on Management of Liabilities in Group Purchasing Organizations QUALITY INNOVATION PROSPERITY-KVALITA INOVACIA PROSPERITA Volume: 23 Issue: 1. Crossref

- Zimon G., Zimon D., (2019a). An Assessment of the Influence of Nominalized Quality Management Systems on the Level of Receivables in Enterprises Operating in Branch Group Purchasing Organizations . QUALITYACCESS TO SUCCESS Volume: 20 Issue: 169.

- Zimon, G., (2018). Influence of group purchasing organizations on financial situation of Polish SMEs, OECONOMIA COPERNICANA, vol.9, Issue: 1 Crossref 